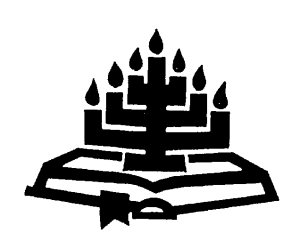

\title{
Jesus se tafelgemeenskap met tollenaars en sondaars: aspekte van 'n missionêre ekklesiologie
}

\author{
J.J.F. Krüger \\ Eenheid vir Reformatoriese Teologie \\ Potchefstroomkampus \\ Noordwes-Universiteit \\ POTCHEFSTROOM \\ E-pos: jjfritz.kruger@gmail.com
}

\begin{abstract}
Jesus' table fellowship with tax collectors and sinners: aspects of a missional ecclesiology

Christian churches with a historically powerful socio-cultural presence often have to adjust to a new marginalised and disempowered existence, stripped of influence in an increasingly secular society dominated by postmodern values. Many churches view this as a threat, and attempt to protect themselves through strengthening of the boundaries between them and the surrounding community, citing the holiness of the church as reason. This results in isolated and exclusive faith communities with no missionary identity, and a split between ecclesiology and missiology. This article proposes that Jesus' table fellowship with tax collectors and sinners provides a motif for restating a missional ecclesiology. Jesus defined his identity as the Holy One of God by removal of boundaries and an inclusive seeking out of the marginalised in the society of his time. He shaped a new community of God's people among them. Likewise, a missional church will understand her holiness not as separation from the world, but as service to God's redemptive purposes, and will devote herself to inviting vulnerability and redemptive entering into the lives of others similar to the incarnation of the Son of God. This will result in the conscious social relocation of the church to the disempowered margins of society, as a sign of the eschatological community of Christ that He continues to gather around Himself in the present.
\end{abstract}




\section{Opsomming}

\section{Jesus se tafelgemeenskap met tollenaars en sondaars: aspekte van 'n missionêre ekklesiologie}

Kerke met 'n geskiedenis van 'n sterk sosio-kulturele teenwoordigheid, moet dikwels aanpas by 'n nuwe gemarginaliseerde bestaan, gestroop van mag en invloed, in 'n toenemend sekulêre samelewing wat gedomineer word deur postmoderne waardes. Baie kerke beskou dit as 'n bedreiging en probeer hulleself beskerm deur die grense tussen hulleself en die omringende gemeenskap te versterk, en die heiligheid van die kerk as rede daarvoor aan te voer. Dit veroorsaak afgesonderde, eksklusiewe geloofsgemeenskappe sonder enige missionêre identiteit, en 'n skeuring tussen ekklesiologie en missiologie. Hierdie artikel stel dat Jesus se tafelgemeenskap met belastinggaarders en sondaars 'n motief daarvoor verskaf om weer 'n missionêre ekklesiologie daar te stel. Jesus het sy identiteit as die Heilige van God gedefinieer deur verwydering van grense en 'n inklusiewe opsoek van die gemarginaliseerdes van die samelewing van sy tyd. Hy het onder hulle 'n nuwe gemeenskap van God se volk gevestig. Net so sal 'n missionêre kerk nie haar heiligheid verstaan as 'n afsonderlike bestaan van die omringende gemeenskap nie, maar die kerk se heiligheid sal eerder as diens aan God se verlossingsdoel manifesteer, en sy sal haarself toewy aan 'n uitnodigende oopstelling en bevrydende betrokke wees in die lewens van ander, op 'n wyse wat gelyksoortig is aan die inkarnasie van die Seun van God. Dit sal 'n bewuste sosiale herposisionering van die kerk na die ontmagtigde buitenste grense van die samelewing tot gevolg moet hê, as 'n teken van die eskatologiese gemeenskap van Christus wat Hy steeds rondom Homself vergader.

\section{Inleiding}

\subsection{Kerklike reaksie op marginalisering en 'n nuwe samelewing}

Kerke' 1 met 'n geskiedenis van 'n sterk sosio-kulturele teenwoordigheid moet vandag dikwels aanpas by 'n meer gemarginaliseerde bestaan, gestroop van mag en invloed, in 'n toenemend sekulêre,

1 Waar in hierdie artikel die woord kerk gebruik word, word dit meestal in die sin van die plaaslike gemeente gebruik. Waar na 'n spesifieke kerkverband verwys word, word die naam daarvan gebruik. Die meervoud kerke verwys na kerke in die algemeen, sonder enige spesifieke begrensing ten opsigte van plek of denominasie. 
multireligieuse en pluralistiese samelewing. In Suid-Afrika ontkom die hoofstroom Afrikaanse gereformeerde kerke ook nie hieraan nie. Byna sonder uitsondering ervaar hulle ook 'n daling in lidmaatgetalle (Olivier \& Van Deventer, 2004:4,10; Lategan, 2005:231, 233, 239; Krüger, 2009:7, 8; Steyn, 2005:552-553; Kruger \& Hofmeyr, 2009:137-138, 141-143).

Dit is nie 'n nuwe verskynsel nie: in Europa het dieselfde proses reeds in die sewentigerjare van die vorige eeu begin, en die wortels van 'n stadige dood van die Christendom in Europa strek terug tot met die opkoms van verligtingsdenke meer as 200 jaar gelede (Lategan, 2005:232-233; Theron \& Lotter, 2008:303). Dit is ook nie noodwendig 'n negatiewe verskynsel of ervaring nie: dit is eie aan die kerk om telkens weer selfkritiese vrae te stel rakende haar rol en relevansie in 'n spesifieke tyd of kairos asook ter wille van die herwinning van haar eintlike identiteit (vgl. Murray, 2001:172-173).

Tog ervaar kerke bogenoemde prosesse dikwels as negatief en as 'n krisis. Later in die artikel word aangetoon hoe sommige kerke so 'n krisis hanteer, en dat die verband tussen ekklesiologie en missiologie dikwels losgelaat word in 'n krisistyd, veral as gevolg van 'n gebrekkige verstaan van die heiligheid van die kerk. Teen die agtergrond van bogenoemde bestaanskrisis van die kerk word die hooflyne van 'n missionêre ekklesiologie getrek, waarin die missionêre en ekklesiologiese weer bymekaar gebring word - maar dan bewustelik binne 'n konteks van die marginalisering en ontmagtiging van die kerk, wat positief gewaardeer word as sake wat die identiteit en roeping van die kerk help definieer, eerder as verduister.

Vir hierdie doel word die tafelgemeenskap van Jesus met tollenaars en sondaars in die Evangelievertellings ontgin. Eers word aandag gegee aan aspekte van Joodse identiteit in die eerste eeu n.C.: die betekenis van Jesus se tafelgemeenskap met tollenaars en sondaars, Jesus se eie verstaan van sy heiligheid, en die redes waarom sy tafelgemeenskap met tollenaars en sondaars so 'n heftige reaksie ontlok het. Vervolgens word enkele aspekte van 'n missionêre ekklesiologie oorweeg, naamlik:

- die heiligheid van die kerk as 'n missionêre heiligheid;

- die wyse waarop die kerk in die omringende gemeenskap teenwoordig kan wees in die lig van die inkarnasie; en

- die bewuste sosiale (her)posisionering van die kerk op die grense van die samelewing. 


\subsection{Metodologiese opmerking}

Bosch (1991:22) merk tereg op: "We cannot reflect on mission today unless we turn to the Jesus of the New Testament, since our ministry is moored to Jesus' person and ministry." Vanuit die oortuiging dat Christologie missiologie behoort te definieer, dat die historiese Jesus die primêre model vir sending is, en die Evangelies die primêre teks is (Frost \& Hirsch, 2003:112), word hier dus op die optrede van die historiese Jesus in die Evangelies gefokus.

Dit moet egter in gedagte gehou word dat daar wesenlike verskille is tussen 'n pre-Christelike en 'n post-Christelike konteks, wat lukrake spronge van die een na die ander onmoontlik maak (Murray, 2001:115). Hierdie feit figureer in die praktiese toepassingsmoontlikhede.

\section{Eerste-eeuse Joodse denke oor heiligheid, Tora en tafelgemeenskap}

\section{1 Die Jode en vreemde oorheersing}

Sedert 63 v.C. het die Jode onder Romeinse oorheersing geleef, wat die fokus van 'n weerstand geword het wat baie jare voortgeduur het. Sommige Jode het oorleef deur 'n kompromie met die vreemde heersers en hulle kultuur aan te gaan. Ander Jode het egter nog meer verbete geword in hulle toewyding aan die verbond, met die hoop dat God die verbond iewers in die toekoms sou herstel tesame met die herstel en bevryding van sy volk en hulle land (vgl. Bosch, 1991:19-20).

In Jerusalem waar die Romeinse invloed die sterkste gevoel is, was die fokus op Joodse identiteit, die tempel en die status van Jerusalem as godstad. In Galilea was die Romeinse teenwoordigheid kleiner, en heidense godsdienstige elemente het meer voorgekom. Hier het die Tora die simbool van Joodse andersheid geword, en later selfs die tempel in Joodse godsdienstige denke vervang. Veral drie aspekte van die Tora het as identiteitsmerkers gegeld: besnydenis, die sabbatswette en die verskillende koswette. Wanneer God eendag sou ingryp om sy volk te bevry en te herstel, sou slegs diegene daaruit voordeel kry wat hierdie grensmerkers van die verbond getrou bewaar het (Wright, 1992:168).

Die Fariseërs was in die middelpunt van die stryd om behoud van die Joodse identiteit. Vanaf die tyd van hulle ontstaan tydens die Makkabese opstande, het hulle hulle vir die behoud van die tra- 
disionele Joodse lewe beywer teenoor die gevaar van die omringende heidendom (Wright, 1992:188). Die Esseense gemeenskappe was nog meer ekstreem in hulle ywer vir afsondering van heidense invloede, veral fisies en ruimtelik (Ferguson, 1987:409).

Hoewel daar baie probleme in die gebruik van bronne oor die Fariseërs bestaan en dit daarom moeilik is om 'n duidelike beeld van hulle te vorm (Wright, 1992:181-184), kan die volgende saamgestelde beeld van die Fariseërs tot 70 n.C. tog met redelike sekerheid gestel word (vgl. Wright, 1992:186-189, 194-195, 213, 228; Sanders, 1985:176-177):

- Die Fariseërs was meer as bloot 'n intellektuele polisie wat oor die regsinnigheid van die volk waggehou het en hulle met geskille oor die toepassing van die Tora en kwessies van rituele reinheid besig gehou het. Hulle fokus het ook politieke kwessies ingesluit, selfs revolusionêre aktiwiteite, en in hierdie opsig het hulle 'n wye invloed gehad.

- Die reinheidswette was baie belangrik, veral in die samehang van Tora en die politieke ambisies van die Fariseërs. Die aandrang op rituele heiligheid het die nasionale vrees vir en 'n weerstand teen besmetting deur heidene ${ }^{2}$ uitgedruk, asook die Joodse weersin in vreemde oorheersing. Die manier om die eskatologiese herstel van Israel te verseker, was deur 'n meer intensiewe bestudering en beoefening van die Tora (vgl. Hamel, 2006:6).

- As gevolg van die korrupsie van die hoëpriesterskap en die gevolglike twyfel oor die werklike geloofwaardigheid van die tempeldiens het die Fariseërs hulleself algaande as die vervanging van die tempeldiens begin beskou; as "alternatiewe priesters" vir wie die Tora se reinheidsvoorskrifte dus ook gegeld het (vgl. Tomson, 2001:96; Hamel, 2006:3).

- Twee strome het ontstaan, naamlik diegene wat in hulle ywer vir die Tora en die Joodse nasionale bestaan selfs deelgeneem het aan vorms van revolusionêre verset teen die Romeine (hoofsaaklik aanhangers van die skool van Shammai, wat dominant was tot 70 n.C.); en 'n meer gematigde groep wat hulle in meditatiewe

2 Die woord heidene word in hierdie artikel gebruik in dieselfde sin as wat die Fariseërs en ander Jode dit sou doen - dit wil sê: as 'n verwysing na mense afkomstig van buite die verbondsgemeenskap van Israel - en nie as 'n neerbuigende of bevooroordeelde begrip ten opsigte van mense buite die Christendom nie. 
bestudering van die Tora teruggetrek het (hoofsaaklik aanhangers van die skool van Hillel, wat eers na 70 n.C. die dominante stroom geword het; vgl. Tomson, 2001:88).

- Die Fariseërs het 'n wye invloed in hierdie tyd gehad. Sommige van hulle leiers (byvoorbeeld Gamaliël) was gerespekteerde politieke leiers, en hulle het opgetree as die de facto leraars van die volk (die priesters was die de iure leraars).

- Hulle het nie van alle gewone Jode verwag om dieselfde hoë standaarde te handhaaf as hulleself nie, 3 maar die respek wat gewone mense vir hulle gehad het, was sodanig dat die farisese ideaal van reinheid en gehoorsaamheid aan die Tora wye aanhang geniet het (vgl. Tomson, 2001:63 \& Hamel, 2006:17). Wright (1992:8) maak die gevolgtrekking dat "The Pharisees represented populist political sentiment and religion", waaruit blyk dat die Fariseërs se idees tot 'n groot mate ook die gewone mense se idees weerspieël het.

\subsection{Identiteit, reinheid en Tora}

Die fokus in die algemene Joodse bewussyn was 'n separatistiese Joodse nasionale identiteit (teenoor hulle vreemde oorheersers en die heidene), en die samehang hiervan met die bestudering en uitleef van die Tora. Die Tora het die belangrikste grensmerker vir toegewyde Jode geword, veral met die oog op die eskatologiese herstel van Israel (Wright, 1992:232, 238; Tomson, 2001:88). Ontrouheid aan die Tora, uitgedruk in 'n sondige leefstyl, het neergekom op hoogverraad teen Israel in politieke én godsdienstige sin (Hamel, 2006:7).

In hulle fokus op die suiwerheid van hulle aparte identiteit en gehoorsaamheid aan die Tora, was die Jode nie werklik besorgd oor mense buite die verbondsgemeenskap nie - nie afvallige Jode óf heidene nie. Vir die hede en die eskatologiese toekoms was soveel op die spel, dat diegene wat alreeds binne die verbondsgemeenskap geleef het, se groot fokus dié van sorg en bearbeiding was. Hulle moes steeds hoër grade van heiligheid en toewyding bereik -

3 Dit kan dus nie gestel word dat die Fariseërs die hele nie-farisese volk (die am ha'arets) as sondaars beskou het en gevolglik uit die koninkryk van God uitgesluit het nie - contra Jeremias en Neusner (vgl. Van Bruggen, 1996:19; Sanders, 1985:176-177). Uiteindelik was nie net die Fariseërs oor Jesus se tafelgemeenskap met die sondaars kwaad nie, maar ook gewone Jode (Luk. $7: 34 ; 19: 7)$. 
ter wille van die toekoms van die verbondsgemeenskap (Bosch, 1991:25). Berou, bekering en versoening het slegs binne die grense van die reeds bestaande verbondsgemeenskap gefunksioneer as maniere waarop Jode hulle integriteit en identiteit as God se volk kon handhaaf. Dit het weinig te make gehad met toetrede tot die verbond van buite af (Wright, 1992:275, 334). Daar was dus nie sprake van die roeping van Israel om as bruggemeenskap na die heidennasies te dien nie (Wright, 1992:267).

\subsection{Tafelgemeenskap as grensmerker in die Joodse samelewing}

Om saam te eet, het dikwels 'n sterk sosiale funksie. In 'n bepaalde gemeenskap kan tafelgemeenskap 'n uitdrukking wees van die korporatiewe bestaan van 'n betrokke gemeenskap. Dit definieer ook die betrokke gemeenskap en tegelykertyd vorm dit die ruimte waarbinne oor lidmaatskap van die gemeenskap beslis word (Reinhartz, 1999:232; vgl. Tomson, 1999:193, 197).

'n Ekstreme voorbeeld van hierdie funksie van tafelgemeenskap in die Joodse samelewing is dié van die Esseners. Een so 'n Esseense gemeenskap was die Yachad-gemeenskap wat in streng afsondering geleef het (Davies, 1999:157, 161). Die lede van die gemeenskap is as priesters beskou wat in 'n afwesige tempel diens doen (uit verset teen die korrupsie in Jerusalem), in 'n gepaste staat van heiligheid. Die heiligheid van die gemeenskap was afhanklik van die heiligheid van elke afsonderlike lid, omdat elkeen as 'n bousteen, altaar en toegangspoort tot die gemeenskap beskou is. Kos en drank funksioneer in so 'n konteks nie slegs om gemeenskap te bewerk nie, maar word 'n simbool van die handhawing van die gemeenskap se integriteit. Die reëls van die gemeenskap het uitdruklik sy lede verbied om saam met afvalliges of buitestaanders te eet: wat een lid eet, eet die hele gemeenskap, rein of onrein.

Hoewel die Fariseërs nie so ekstreem was nie, het bepaalde idees van die Esseners tóg 'n invloed op hulle denke gehad (Tomson, 2001:50). Daar was bepaalde farisese groepe wat ook tafelgemeenskap as 'n kragtige middel vir sosiale beheer gebruik het (Tomson, 1999:198), hoewel nie alle Fariseërs hierin meegedoen het nie. Oor die algemeen het die reëls vir tafelgemeenskap onder die Jode op twee pilare gerus: sommige voedselsoorte is verbied, omdat dit op sigself onrein was soos byvoorbeeld varkvleis; ander voedselsoorte, eetgerei, implemente en persone is ook vermy omdat hulle op een of ander manier betrokke was by of gebruik is in afgodsdiens. Omdat afvallige Jode en heidene almal oor een kam geskeer is as 
afgodsdienaars, is tafelgemeenskap met hulle as verbode beskou, omdat dit die deelnemers ook almal onrein sou maak (Tomson, 1999:200).

Die weiering om met iemand in tafelgemeenskap te deel, kom dus neer op die veroordeling en verwerping van so 'n persoon as inherent onrein. Dit is ook as 'n vorm van sosiale beheer gebruik om ongewenste gedrag te bekamp (Sahu, 2008:2). Aan die ander kant was 'n uitnodiging tot tafelgemeenskap, of die instemming om met iemand aan tafel te gaan, 'n uitdrukking van aanvaarding, en erkenning dat hy/sy 'n volledig lid is van die verbondsgemeenskap van Israel (vgl. Hamel, 2006:10). In die eerste eeu was maaltye dus uitstekende geleenthede om grense te trek, om samehorigheid te versterk, en belangrike sosiale waardes te onderstreep. Lojaliteit aan God en die verbond het uitdrukking gevind in die eet van die regte soort kos saam met die regte soort mense; dit was op sy beurt weer uitdrukking van die ideale Israel as God se afgesonderde volk (Hamel, 2006:13).

\section{Jesus se tafelgemeenskap met tollenaars en sondaars}

In die Evangelies is dit duidelik dat Jesus 'n gewoonte daarvan gemaak het om saam met tollenaars en sondaars te eet, omdat Hy dit as kragtige middel kon gebruik in sy verkondiging oor die koninkryk van God (Hamel, 2006:21; Sahu, 2008:10). Nie net is dit 'n tema wat dwarsdeur die Evangelies voorkom nie, ${ }^{4}$ maar uit die gebruik van bepaalde werkwoorde (soos die praesens in Luk. 15:2) is dit duidelik dat Hy dit aangehou doen het (vgl. Van Bruggen, 1993:143).

\subsection{Jesus se tafelgenote}

Wie was die mense saam met wie Jesus aan tafel gegaan het?

- Tollenaars: in die konteks van die Romeinse oorheersing, was die belasting wat die Jode moes betaal 'n direkte aanslag op die Jode se voorvaderlike regte en hulle besit van die land wat in die verbond aan hulle belowe is. Tollenaars is dus as veragte verraaiers van die Joodse volk en die verbond beskou (Bosch,

$4 \quad$ Markus 2:13-17; 6:30-44; 8:1-10; Matteus 8:11-12; 11:19; 21:31-32; Johannes $2: 1-11 ; 21: 1-14$; Lukas 7:36-50; 10:38-42; 11:37-54; 14:1-24; 15:1-32; 19:1-10; 24:13-35. In alle gevalle word die ooreenstemmende parallelle tekste ook ingesluit. 
1991:26-27) wat die eskatologiese bevryding van die volk in gevaar gestel het.

- Sondaars: in die Nuwe-Testamentiese wetenskap is algemeen aanvaar (onder invloed van Jeremias en Neusner) dat die kategorie van sondaars in die Evangelies na alle Jode verwys wat nie die Fariseërs se streng reinheidsvoorskrifte nagekom het nie (die sogenaamde 'am ha'arets). Sanders (1985:177-178) bewys egter dat dit nie die geval is nie. Die sondaars is mense wat bewustelik en grof gesondig het en geen berou getoon het nie. Dus het sulke persone nie slegs die Tora verwerp nie, maar ook die gesag van God én God self. Soms was hulle die slagoffers van omstandighede (vgl. arm vroue wat hulleself as prostitute aan Romeinse soldate verkoop het om kos op die tafel te kry), maar meestal was hulle bloot mense wat moreel-problematiese beroepe beoefen het asook mense van twyfelagtige karakter (Bosch, 1991:27; vgl. ook Bolkestein, 1966:67; Van Bruggen, 1996:19; Luk. 7:37, 39; Matt. 21:31-32). Ook hierdie mense het in hulle oortreding van die Tora die aparte identiteit van die Joodse volk in gevaar gestel en die toekomstige bevryding van die volk in die gedrang gebring.

- Heidene: Blomberg (2005:110-111) maak 'n sterk saak daarvoor uit dat die skare by die tweede vermeerdering van die brood en vis (vgl. Mark. 8:1-10) ook heidene ingesluit het. In die eerste plek wys hy daarop dat Jesus hierdie wonder in Dekapolis doen tydens sy besoek aan die streek van Tirus en Sidon, wat 'n oorwegend heidense gebied was. Hy sê verder dat baie van hulle "van ver af" gekom het, en gebruik daarby 'n uitdrukking wat veral in die teks van die Septuagint vir mense uit die heidennasies gebruik word (vgl. Jes. 60:4; Jer. 38:10; 46:27). Die skare word ook nie ingedeel in groepe van 100 en 50 nie, wat moontlik verwys na Israel in die tyd van Moses (Mark. 6:40), terwyl die aantal mandjies wat hierdie keer oorbly nie twaalf is nie (Mark. 6:43 - 'n moontlike verwysing na die twaalf stamme van Israel), maar sewe. Laastens staan ook in Matteus 15:31 dat die mense in daardie streek "die God van Israel" geprys het oor Jesus se wonders. Dit lyk na 'n geldige interpretasie, wat beteken dat Jesus tydens hierdie besoek aan Dekapolis, Tirus en Sidon, ook die heidene in die reikwydte van sy sending ingesluit het; én in 'n vorm van tafelgemeenskap wat (net soos die eerste vermeerdering van brood en vis), vooruitwys na die messiaanse feesmaal. In albei die vermeerderingswonders is daar geen verwysing na reinigingsrituele of die nakoming van die koswette van die 
Jode nie: Jesus het bloot gedank en die mense het geëet (vgl. Green, 1997:365).

\subsection{Die betekenis van Jesus se tafelgemeenskap}

Wat doen Jesus wanneer Hy met hierdie mense saameet? Op 'n aanskoulike manier dui $\mathrm{Hy}$ aan dat die langverwagte teenwoordigheid en heerskappy van God aangebreek het tussen die nederige, veragte mense van sy volk en die heidene - die sosiaal gemarginaliseerdes van sy tyd, wat ook die armes, siekes, gestremdes en weduwees ingesluit het - en nie tussen die mense wat hulleself as die eintlike volk van God reken nie (Luk. 5:31-32). Wat Jesus in sy tafelgemeenskap aan sy tafelgenote skenk, kan die beste uitgedruk word met die Griekse begrip aphesis (gewoonlik vertaal met vergifnis - vgl. Luk. 7:48). Breed gesproke verwys dit na die bevryding van slawe, kwytskelding van geldskuld, eskatologiese bevryding van die volk van God, of juridiese vergewing van sonde - aspekte wat almal na die allesomvattende aard van God se heerskappy wys. Dit kom neer op die opheffing van elke vorm van vervreemding (Bosch, 1991:33), en dus insluiting in God se nuwe gemeenskap van genadige bevryding. Op hierdie manier word Jesus se maaltye met sy vreemde tafelgenote meer as tekens van feesviering: dit word tekens van bevryding en versoening (Sahu, 2008:9).

Het Jesus van die tollenaars en sondaars bekering gevra? Dit word soms ontken (Sahu, 2008:11), maar in byna al die verwysings na tafelgemeenskap is ' $n$ ondertoon van berou en bekering (Van Bruggen, 1993:143 \& 1996:158-159; Blomberg, 2005:101; Klein, 2006: 226; Luk. 5:31-32), hoewel dit slegs van Levi en Saggeus staan dat hulle hulle bekeer het (Nielsen, 1979:164; Mark. 2:14; Luk. 19:8).

Wat egter wel duidelik is, is dat Jesus nooit van mense geëis het dat hulle hulle éérs moet bekeer en daarna eers welkom sou wees om saam met Hom te eet nie (Hamel, 2006:19, teenoor Van Bruggen, 1993:289). Jesus het deur die aanvaarding van sy tafelgenote laat blyk dat hulle mense is vir wie God liefhet en Hy het hulle geleer oor die koninkryk van God, waarna sommiges hulle tot Hom bekeer het. Groot skares tollenaars en sondaars het Hom opgesoek, wou na sy onderrig en prediking luister, en was gefassineer deur hierdie Man. Saggeus is 'n sprekende voorbeeld hiervan - en ook van iemand wat eers ná die ervaring van Jesus wat saam met Hom eet, tot berou en daadwerklike bekering gekom het (Luk. 19:1-10). Hierdie punt is van groot belang vir die ekklesiologiese besinning wat hieronder volg. 


\subsection{Die aanstoot van Jesus se tafelgemeenskap}

Waarom het Jesus se optrede soveel aanstoot gegee (vgl. Luk. 15:1-2; Sanders, 1985:288)? Jesus het doelbewus tollenaars, sondaars en ander kategorieë mense wat deur die Jode as onrein beskou is, ingesluit in die gemeenskap van die ideale Israel terwyl hulle nog sondaars was, sonder om voorwaardes van bekering of rituele reiniging te stel. Hiermee dekonstrueer Jesus die Joodse nasionale simbole en reinheidsdenke, en laat $H y$ as 't ware ' $n$ gelykenis van die nuwe Israel sien (Hamel, 2006:18): sy maaltye met hierdie mense, wys vooruit na die messiaanse feesmaal aan die einde van die tyd (Blomberg, 2005:101; Bolkestein, 1966:67), wanneer dit duidelik sal word wie die ware Israel is (dus ook tollenaars, sondaars, prostitute en heidene), tot groot ontsteltenis van die Fariseërs en ander Jode!

Die enigste voorwaarde vir hulle insluiting was dat hulle Jesus aanvaar, in Hóm glo, en gemeenskap met Hóm soek. Jesus systap hiermee die soteriologiese funksie van die Tora en die tradisies van die Jode asook die funksie van die tempel, die priesters, die Fariseërs en alles waarvoor hulle gestaan het. In die plek van al hierdie dinge stel Hy slegs Homself en aanvaarding of navolging van Hóm (vgl. Sanders, 1985:206, 208-210, 255; Bosch, 1991:34, 37; Hamel, 2006:1, 20; Goppelt, 1976:181). Hierin lê die groot aanstoot vir die Jode.

\subsection{Jesus se identiteit en heiligheid}

Hoe verskil Jesus se hantering van sy eie identiteit en heiligheid van dié van die Jode van sy tyd? Dit is duidelik dat Jesus in sy kontak met die tollenaars en sondaars nooit bang is dat hy self onrein sal word nie. Ten diepste dink Hy hoegenaamd nie in reinheidskategorieë oor mense nie, en daarom gaan Hy ook nie dienooreenkomstig met mense om nie.

Jesus se hantering van sy eie heiligheid is nie selfbeskermend, eksklusief of negatief nie, maar positief en inklusief (Sahu, 2008:10). Hy betree die sfeer van onrein mense en definieer sy eie identiteit in nederige, kwesbare selfopoffering (Fil. 2:7-8), waarmee Hy God se liefde vir mense sigbaar maak. Waarom is Hy kwesbaar? Omdat Hy op geen manier probeer om Homself of sy heiligheid te beskerm nie, maar Hom eerder aan moontlike misverstand, veragting en bespotting uitlewer, asook 'n insluiting in die kategorie van die tollenaars en sondaars, as 'n dronklap en 'n vraat (Matt. 11:19; vgl. Deut. 21:20). 
Sy identiteit as die Heilige van God (Mark. 1:24; Luk. 4:34; Joh. 6:69) is nie gedefinieer deur streng grense te handhaaf nie, maar juis deur sy opheffing van alle grense in liefdevolle omgang met hulle wat onrein is. Hiermee maak Hy God se heilige liefde sigbaar (Hos. 11:9), bevestig sy identiteit en is volledig gehoorsaam aan God se opdrag (Joh. 5:30). Jesus se tafelgemeenskap met tollenaars en sondaars is die noodsaaklike gevolg van sy inkarnasie. Hy neem die gestalte van 'n slaaf aan, die minste onder mense; sodoende word Hy werklik aan mense gelyk; só kom woon Hy "onder ons" (Joh. 1:14).

\section{Die heiligheid van die kerk}

\section{1 'n Reaksionêre verstaan van die kerk se heiligheid}

In die inleiding hierbo is na kerke se worsteling met sosiale marginalisering verwys asook die invloed van postmodernisme en religieuse pluralisme. Omdat die nuwe situasie dikwels as 'n bedreiging ervaar word - 'n "totale aanslag" op die bestaan van die kerk en alles waarvoor sy staan (vgl. Bosch, 1991:376) - reageer geloofsgemeenskappe dikwels met selfbeskermende optrede. Fundamentalisme is een van die kenmerkende reaksies (Vorster, 2004:595, 597), en verteenwoordig

- 'n reaksie teen sosiale marginalisering, persoonlike isolasie en die verlies van kulturele en etniese identiteit;

- 'n soeke na ewige waardes, 'n stabiele wêreldbeskouing, en die instandhouding van tradisie; en

- 'n skerp onderskeid tussen waarheid, valsheid en geslote denksisteme soos tradisionalisme en ortodoksisme, wat met verset teen verandering saamhang (vgl. (Steyn, 2005:552, 554, 558).

In 'n konteks van bedreiging fokus kerke dikwels baie skerp op (her)definiëring van hulle eie identiteit, en ook op die afbakening van hierdie identiteit deur die handhawing van duidelike grense (vgl. Tomson, 1999:195-197; 2001:104). Hoe groter die gevoel van bedreiging, hoe sterker word die grense bewaak en hoe meer eksklusief word die identiteit gedefinieer. Identiteitsmerkers word daarom baie belangrik. Die lees en interpretasie van die Bybel (net soos sekere leerstellige sake), speel 'n belangrike rol. Bepaalde interpretasies word feitlik gekanoniseer ten einde leerstellige sekerheid te skep; en bepaalde etiese norme van die Bybel word die grensmerkers wat aandui wie hulleself "binne" en "buite" die gemeenskap bevind. Veral sekere sleutelsake word tot absolute standaarde ver- 
hef. In die Jodedom van die eerste eeu n.C. is die reinheidsvoorskrifte van die Tora byvoorbeeld sodanig verabsoluteer (Tomson, 2001:88). In ons tyd is dit dikwels ander sake soos die debatte binne die GKSA oor vroue in die besondere dienste, die wyse van nagmaalviering en die kerklied wat die afgelope aantal nasionale sinodes oorheers het.

Ekklesiologies gesproke het dit 'n pre-okkupasie met die eie identiteit en grensmerkers van die kerk tot gevolg - 'n soort ekklesiologiese narsisme waarin die kerk haar feitlik eksklusief in haar eie bestaan verdiep (Berkouwer, 1972:134). Sy beroep haar ook veral sterk op haar heiligheid as afsondering van "die wêreld" (Berkouwer, 1972:149; Frost \& Hirsch, 2003:54) deur die handhawing van haar ortodoksie en ortopraksie teenoor "die wêreld" (Hoek, 2008:28). Frost en Hirsch (2003:132) som dit op as "holiness by negation or holiness by avoidance", wat funksioneer op die basis van 'n strak skeiding tussen die sakrale en die profane ruimtes van ons wêreld (Frost \& Hirsch: 2003:10). Wat gewoonlik in die slag bly wanneer die kerk so narsisties besig is, is haar bewussyn van haar taak na buite: ekklesiologie en missiologie word van mekaar geskei, en die kerk se missionêre identiteit gaan verlore.

\subsection{Missionêre heiligheid}

In die Bybel is dit duidelik dat die heiligheid van die kerk wél 'n fundamentele andersheid van die kerk veronderstel (Joh. 17:14-17) op grond van die heiligende werk van die Heilige Gees (2 Tim. 2:13) en die bloed van Christus (1 Pet. 1:2). Die heiligheid van die kerk is dus 'n toegekende (of toegerekende) heiligheid en nie in die eerste plek te soeke in die moreel-etiese volmaaktheid van die kerk of haar lede nie - iets wat in elk geval onhaalbaar is (vgl. Küng, 1976:422 se verwysing na die kerk as casta meretrix). Tog is die sigbare andersheid van die kerk 'n noodsaaklike voorwaarde vir haar getuienistaak in die omringende gemeenskap (Berkhof, 1979:419; Bosch, 1991:388; 1 Pet. 1:15-16 \& 2:12).

Maar hierdie heilige andersheid is nie 'n doel op sigself nie, en mag ook nie die veiligheid of selfbeskerming van die kerk in 'n vyandige konteks dien nie. Veral uit die Ou Testament is dit duidelik dat die konsep van afsondering en andersheid, wat in die begrip heiligheid voorkom, sekondêr is (Eichrodt, 1961:137). Primêr beteken heiligheid om aan God te behoort; om toegewy te wees aan God se doel, en Hom dáárom in alles te gehoorsaam (Kaiser, 1978:105; Eichrodt, 1961:137; Berkouwer, 1972:136-137; Van Genderen \& Velema, 1992:648). As heilige volk van God was Israel veral geroep tot 'n 
priesterlik-bemiddelende rol ten opsigte van die ander nasies. Hieroor skryf Kaiser (1978:111): "Holiness was conditioned upon the mediatorial role of Israel: holiness serves mediation, not selfpreservation but the redemption of others." Hoe streng die Jode in Jesus se tyd hulle grense as die volk van God ook teenoor die omringende heidendom bewaak het, was hulle tóg nie heilig soos God dit bedoel het nie, omdat hulle nie toegewy was aan God se missionêre doel met hulle ten opsigte van die nasies nie. Dit geld ook vir die kerk van die Nuwe Testament, die gemeenskap van Christus (Küng, 1976:417, 419; 1 Pet. 2:9-10).

Die heiligheid van die kerk is bedoel om na buite gerig te wees as 'n bevrydende, missionêre heiligheid (Frost \& Hirsch, 2003:132; Devenish, 2005:24-25). Dit verwys nie narsisties en refleksief na die kerk nie, maar na God se karakter, hart en doel (Davie, 2005:62). Dit is nie in die eerste plek ' $n$ morele kwaliteit nie, maar is fundamenteel aan God se verlossingsdoel met die wêreld verbind: Hy heilig die kerk ter wille van die verlossing van hulle wat nog nie in Christus is nie (1 Pet. 2:9-10), en die kerk heilig God se naam deur sy liefdevolle soeke na gemeenskap met die verlore mense van die wêreld te verkondig én konkreet gestalte te gee (vgl. Eichrodt, 1961:281). Heiligheid wat buite God se missionêre verlossingsdoel met die kerk én die wêreld gesoek word, is nie heiligheid nie, maar selfbeskermende sonde.

God se onverklaarbare, verlossende liefde is 'n uitdrukking van sy heiligheid, sy volstrekte andersheid (Hos. 11:9). Hieroor skryf Eichrodt (1961:281): "the relation of the Holy One to the world [in Isaiah] acquires its dynamic entirely from the divine eschatological purpose of redemption". Die kerk se heiligheid moet daarom ook geleë wees in die anderse, verlossende manier waarop sy in liefde met ander omgaan, met die liefde van Christus self: nie in eksklusiewe selfbeskerming nie, maar in die afbreek van haar eie grense, sodat sy by mense kan kom van wie niemand gereken het dat hulle die voorwerp van God se liefde kan wees nie. Sy leef haar nuwe lewe onder diegene wat Christus nie ken nie (Frost \& Hirsch, 2003:54): weerloos, kwesbaar en inklusief, maar gedra en beskerm deur die teenwoordigheid van Hom wat belowe het om by haar te wees, juis in haar ingaan in en opsoek van die wêreld (Matt. 28:16-20).

Oor sodanige verstaan van die heiligheid van die kerk, skryf Frost en Hirsch (2003:133):

It is a missional holiness. It moves to change the world, to sanctify it. ... it is active in every sphere of life and does not shirk 
back from the redemption of dark things. Holiness partners with God in the redemption of the world.

\section{Die wyse waarop die gemeente in die wêreld teenwoordig is}

\subsection{Die inkarnasie as grondmotief}

'n Missionêre ekklesiologie moet in terme van die inkarnasie van Christus ontwikkel word (Smit, 2008:110). As die liggaam van Christus en "die volheid van Hom wat alles in almal vervul" (Ef. 1:22-23), word die kerk van Christus saam met haar Hoof geneem om op Sý manier in die wêreld teenwoordig te wees. Christus is konkreet teenwoordig in sy kerk (Matt. 18:20 \& 28:20), wat omgekeerd ook beteken dat die kerk ten minste één manier van Christus se teenwoordigheid in die wêreld vergestalt (Ef. 3:10; Christus word immers nie volledig in die kerk bevat nie - Küng, 1976:307).

Die inkarnasie van die Seun van God was die grondmotief vir die manier waarop Hy in die wêreld gestaan het (Fil. 2:7-8): nederig, sonder om toe te gee aan die versoeking van mag en rykdom (Matt. 4:8-10), sonder selfbeskerming, gelyk aan die minstes onder mense, in intieme nabyheid aan die gemarginaliseerdes van die samelewing van sy tyd. 'n Kerk wat hieraan gestalte wil gee, sal in haar ontmagtiging en marginalisering in 'n veranderende samelewing, nie noodwendig 'n bedreiging sien nie, maar 'n geleentheid om na haar eintlike identiteit terug te keer (vgl. Frost \& Hirsch, 2003:54, 112).

Frost en Hirsch $(2003: 12,44)$ maak in hierdie verband 'n bruikbare onderskeid tussen 'n "missional incarnational church" enersyds, en 'n "attractional church" andersyds. 'n Missionêre kerk wat in die teken van die inkarnasie wil kerk wees, skep nie heilige ruimtes waar ongelowiges moet inkom om met die evangelie in aanraking te kom nie, terwyl 'n "attractional church" juis dit doen. In laasgenoemde soort kerk word evangelisasie daarop gefokus om ongelowiges kerk toe te bring: "Rather than being genuine 'out-reach', it effectively becomes something more like 'drag-in'." (Frost \& Hirsch, 2003:41.) Daarteenoor skryf Frost en Hirsch (2003:12) oor 'n werklike missionêre kerk: "The missional church disassembles itself and seeps into the cracks and crevices of a society in order to be Christ to those who don't yet know him." Dit is wat Christus self ook gedoen het in sy maaltye met die onfatsoenlike mense van sy tyd. Hy het Homself nie opgesluit in die sinagoge, die tempel, of die geselskap van die rabbi's, wetsgeleerdes, priesters, en Fariseërs nie, maar oor al hierdie grense van Joodse godsdienstige fatsoenlikheid getree om tus- 
sen die onfatsoenlikes gestalte te gee aan 'n teken van die teenwoordige en komende ryk van God.

\section{2 'n Kerk tussen en vir mense}

Wat beteken dit konkreet vir die wyse waarop die kerk in die wêreld leef vandag? Bosch (1991:34) waarsku tereg dat ons nie sommer van Jesus se werkswyse in sy tyd moet ekstrapoleer en Hom bloot moet naboots in ons tyd nie. Hy sê: "we are challenged to let Jesus inspire us to prolong the logic of his own ministry in an imaginative and creative way amid changed historical conditions".

Dit beteken dat die blote maaltye saam met prostitute, haweloses, gevangenes en ander randfigure van ons samelewing 5 nie noodwendig die manier is waarop die kerk Jesus se tafelgemeenskap met tollenaars en sondaars moet voortsit nie. Dit beteken ook dat ' $n$ mens nie sommer goedskiks die lyn moet trek tussen Jesus se maaltye met tollenaars en sondaars, en die nagmaal nie (vgl. byvoorbeeld Wadell, 2007:80; Edmondson, 1991). Jesus se maaltye met tollenaars en sondaars was 'n uitnodiging om Hom te aanvaar en te deel in 'n nog voller gemeenskap met Hom, naamlik die geloofsgemeenskap van mense wat deel het aan sy dood en opstanding, waarvan die nagmaal 'n konkrete vergestalting is. Hierdie twee soorte maaltye staan dus aan weerskante van die geloofsbeslissing om Jesus te volg. Dit was nie sonder rede dat Jesus die nagmaal binne die klein kring van slegs die twaalf dissipels ingestel het nie, en ook nie sonder rede dat Paulus in 1 Korintiërs 11:29 'n hoë geloofseis aan deelnemers aan die nagmaal stel nie.

Frost en Hirsch (2003) stel vier maniere voor waarop die kerk vandag missionêr en op die spoor van die inkarnasie van die Seun van God teenwoordig kan wees in die wêreld:

5 Wanneer hier en elders in die artikel van "randfigure van die samelewing" gepraat word, verwys dit na mense wat hulle vanuit die oogpunt van die breë samelewing (en miskien ook vanuit hulle eie oogpunt) op die marges van die samelewing bevind. Die nuwe posisie van die kerk op die marges van die samelewing is eweneens 'n posisie gedefinieer uit die oogpunt van die breë samelewing. Kerke word hulle toenemend hiervan bewus, maar hulle denke oor mense buite "die kerk" is dikwels nog opvallend dieselfde as dié van die breë samelewing. Geloofsgemeenskappe identifiseer hulle daarom dikwels nog nie met die ander "randfigure" wat nou hulle naaste bure geword het nie, maar benader hulle nog vanuit die ou paradigma van magsdenke. Dit is hoofsaaklik te wyte aan die era toe die perspektief van die kerk en die breë samelewing grotendeels saamgeval het. 
- ontwikkel interpatie en kontekstualiseer: dit is nie dieselfde as empatie of simpatie nie, maar verwys na die vermoë van 'n buitestander in 'n bepaalde gemeenskap om die pyn, ideale, drome en waardes van daardie gemeenskap só akkuut aan te voel, dat hy/sy prakties een van daardie groep kan word. Op grond van hierdie in- en aanvoeling kan nabyverhoudings met mense gebou word, daar waar hulle in die daaglikse lewe leef - wat mag insluit "to share a beer with me and see how I clip my roses" (Frost \& Hirsch, 2003:64);

- kweek 'n spiritualiteit van betrokkenheid (Frost \& Hirsch, 2003: 112): dit is die teenoorgestelde van 'n spiritualiteit van askese en dui aan dat die kerk nie in 'n heilige wêreldjie terugtrek waar sy geen idee het van wat in die wêreld daar buite gebeur nie. 'n Missionêre spiritualiteit van betrokkenheid is een wat na elke moontlike manier soek om alles in die daaglikse lewe te heilig deur dit onder die heerskappy van Christus en in sy diens te stel (Kol. 1:15-20) en wat daarom nie bang is om in die naam van Christus in die donkerste dele van die wêreld in te beweeg om daar sy lig te bring nie. Jesus het doelbewus die tafels van tollenaars en sondaars opgesoek, en daarmee die reputasie van 'n dronklap en vraat gekry; dit het Hom egter nie daarvan weerhou om dit telkens weer te doen nie;

- skep ruimtes van nabyheid: dit is wat Frost en Hirsch (2003:24) "proximity spaces" noem - plekke en geleenthede waar Christene en nog-nie-Christene op 'n sinvolle manier met mekaar kan omgaan, sodat betekenisvolle verhoudings en netwerke binne ' $n$ bepaalde gemeenskap kan groei. 'n Missionêre kerk wat Christus in sy inkarnasie en leefstyl navolg, gaan daarvan uit dat dit noodsaaklik is om naby aan mense te kom daar waar hulle leef, werk en ontspan. Frost en Hirsch (2003:25) skryf hieromtrent: "If Jesus were on earth you'd find him in a gay bar in San Francisco." Ander maniere waarop dit kan gebeur is waar 'n kerk 'n kroeg of koffiewinkel bedryf, 'n kleuterskool oprig, of op enige ander manier struktureel in die behoeftes van 'n bepaalde gemeenskap voorsien word om sodoende in aanraking te kom met mense in hulle alledaagse lewe en nie net as kerkgangers nie;

- verander van 'n grensbewuste na 'n middelpuntbewuste kerk: kerke wat volgens die aantrekkingsmodel funksioneer en aanvaar dat nie-Christene "kerktoe" moet kom om hulle te bekeer, is gewoonlik baie bewus van die grense wat hulle van nie-lidmate onderskei. Verskillende grensmerkers dien hierdie doel, veral 'n groot verskeidenheid moreel-etiese en kerklike reëls (Frost \& 
Hirsch, 2003:47, 48). 'n Missionêre kerk, daarenteen, word nie deur haar grense aan die buitekant gedefinieer nie, maar deur dit wat in die kern van haar bestaan lê - die evangelie wat so kosbaar is dat mense wat Christus werklik liefhet, nie ver daarvan af sal wegbeweeg nie, en ander wat werklik dors is, sal nader beweeg aan hierdie kern. So 'n kerk funksioneer nie met die onderskeid tussen lidmaat en nie-lidmaat nie, maar met graadverskille ten opsigte van hoe naby of ver mense van die kern af leef. In haar bediening fokus so ' $\mathrm{n}$ gemeente daarop om mense nader aan Jesus te help kom, sodat hulle al meer soos Hy kan word. Enigiemand is welkom om deel van hierdie gemeenskap te wees - of hulle ook al verslaaf is aan dwelms, ongetroud saamwoon, gay is, of op enige ander manier tot die randfigure van die samelewing behoort. Kerkwees gaan dan oor die ontwikkeling van dissipelskap, oor 'n proses waarin mense nie eers aan 'n lang lys voorwaardes moet voldoen voordat hulle as deel van die gemeenskap gereken word nie; maar eerder tyd, ruimte en liefdevolle begeleiding gegee word om nader aan Christus te groei en so mettertyd die konsekwensies van 'n lewe met Christus te ontdek. Die kwaliteit van die onderlinge liefdesverhoudings (in die naam van Christus) binne so 'n geloofsgemeenskap is die gom wat dit saambind (Kol. 3:14). In die kern van so 'n gemeente sal 'n duidelike, ononderhandelbare stel geloofsoortuigings wees, gewortel in Christus en sy Woord. Dit moet soos 'n magneetveld funksioneer wat alles in sy kragveld oriënteer om sy patrone te volg en sigbaar te maak, en alles na die middelpunt toe aantrek. 'n Gemeente wat dus rondom die evangelie van Jesus Christus gesentreer is, sal tegelyk eksentries gefokus wees op die gemeenskap rondom haar.

\section{Die gemeente op die grense van die samelewing}

In die lig van bogenoemde is dit reeds duidelik dat 'n missionêre kerk doelbewus op die randfigure van ons samelewing sal fokus; op mense wat deur die algemene fatsoenlikheid van die kerk én die gewone wyer samelewing uit die volle lewe verban en op die buitenste randjie gehou word (Bosch, 1991:18, 34, 373, 386). Dit is die mense wat Jesus aangedui het met die term siekes (Luk. 5:31-32; Nielsen, 1979:164), en die tollenaars en sondaars met wie Hy saamgeëet het. In haar eie marginalisering herken die kerk hierdie randfigure as haar naaste bure.

Die grense waardeur mense vandag uit die hoofstroomsamelewing en die kerklike gemeenskap uitgesluit word, is baie divers en sluit etniese, ekonomiese, sosiale, politieke, geslagtelike, fisiese, intellek- 
tuele, opvoedkundige en godsdienstige grense in (Wadell, 2007:76). Die definisie van wie hierdie vreemdelinge is en waarop die kerk haar daarom moet lokaliseer, verskil van gemeenskap tot gemeenskap:

- vir die gemiddelde Afrikaanssprekende, blanke gereformeerdes is dit waarskynlik haweloses, verslaafdes, gaypersone, mense wat ongetroud saamwoon, mense van ander etniese en taalgroepe, en die inwoners van townships en plakkerskampe;

- vir die inwoners van townships en plakkerskampe is dit waarskynlik buitelanders en vlugtelinge wat tussen hulle kom woon het, dikwels amakwerekwere ${ }^{6}$ genoem - die fokus van xenofobiese geweld; en

- vir Zoeloes met 'n tradisionele leefstyl op die platteland van SuidAfrika, is dit waarskynlik VIGS-lyers en mense van wie vermoed word dat hulle met towery te make het.

Kerke neig om met mense om te gaan wat soos hulle is, in 'n kerklike monokultuur, homogene sosiale enklaves waar almal dieselfde kleur is, dieselfde taal praat, en in dieselfde belastingkategorie val 'n tendens wat lynreg staan teenoor Jesus se tafelpraktyk (Wadell, 2007:76). Wadell (2007:77) sê hieroor:

Christian congregations are called to imitate the 'tabel manners' of Jesus by being sacraments of God's hospitality in the world $[\ldots]$, welcoming, caring for, befriending the stranger, the poor, the needy, the homeless and destitute, the unloved and unlikable, the weird and the strange ... in imitation of Christ.

Hierin laat missionêre kerke hulle lei deur die fundamentele werklikheid dat God in die geskiedenis van sy bemoeienis met die mensdom altyd na die mees onwaarskynlike mense gekom het om hulle op te soek en in sy gemeenskap in te sluit (Frost \& Hirsch, 2003:42, 174).

Die sosiale marginalisering van die kerk en haar nuwe posisie in 'n pluralistiese, postmoderne wêreld is daarom 'n geleentheid om haarself doelbewus sosiaal te herposisioneer op 'n manier wat pas by wie sy ten diepste is. Sy is die liggaam van díe Christus wat ter wille van mense self mens geword het, slaaf geword het, soos ons geword het en tot in die dood aan die kruis gehoorsaam was - ter wille 
daarvan dat elke tong uiteindelik sal bely dat Hy die Christus, die Seun van God is (Fil. 2:6-11).

\section{Gevolgtrekking}

In hierdie artikel is aangetoon dat Jesus se tafelgemeenskap met tollenaars en sondaars 'n kragtige motief is in die daarstel van ' $n$ missionêre ekklesiologie. Dit is veral nodig in 'n tyd waar die toenemende marginalisering van die kerk in 'n veranderde, postmoderne wêreld, 'n kerklike identiteitskrisis tot gevolg het. Baie kerke reageer hierop deur hulle op hulle heiligheid as afsondering van "die wêreld" te beroep. Op 'n selfbeskermende wyse maak hulle hulleself hierdeur ekklesiologie en missiologie los van mekaar. Jesus se gewoonte om met tollenaars en sondaars te eet, bied ' $n$ moontlikheid om die heiligheid van die kerk anders te verstaan, naamlik as 'n grenslose, inklusiewe, gemeenskapsoekende en daarom missionêre heiligheid. Indien sy haarself so verstaan, kan die kerk op die wyse van die inkarnasie van die Seun van God in die wêreld teenwoordig wees: nie selfbeskermend nie, maar weerloos tussen die gemarginaliseerde mense van die wêreld, ten einde dáár 'n nuwe geloofsgemeenskap te vorm as teken van die eskatologiese gemeenskap wat Jesus steeds besig is om rondom Homself te vergader.

\section{Geraadpleegde bronne}

BERKOUWER, G.C. 1972. De kerk: apostoliciteit en heiligheid. Vol. 2. Kampen: Kok. (Dogmatische Studiën.)

BLOMBERG, C.L. 2005. Contagious holiness: Jesus' meals with sinners. Downers Grove: InterVarsity.

BOLKESTEIN, M.H. 1966. Het evangelie naar Marcus: de prediking van het Nieuwe Testament. Nijkerk: Callenbach.

$\mathrm{BOSCH}$, D.J. 1991. Transforming mission: paradigm shifts in theology of mission. Maryknoll: Orbis.

DAVIE, M. 2005. The church of Jesus Christ and Anglican response. Ecclesiology, 1(3):59-86.

DAVIES, P.R. 1999. Food, drink and sects: the question of ingestion in the Qumran texts. (In Brenner, A. \& Van Henten, J.W., eds. Food and drink in the biblical worlds. Atlanta: Society of Biblical Literature. p. 151-163.) (Semeia 86.)

DEVENISH, D. 2005. What on earth is the church for? A blueprint for church based mission and social action. Milton Keynes: Authentic.

EICHRODT, W. 1961. Theology of the Old Testament. Vol. 1. London: SCM.

EDMONDSON. S. 1991. Opening the table: the body of Christ and God's prodigal grace. Anglican theological review, 91(2):213-234.

FERGUSON, E. 1987. Backgrounds of early Christianity. Grand Rapids: Eerdmans.

FROST, M. \& HIRSCH, A. 2003. The shaping of things to come: innovation and mission for the 21st century church. Peabody: Hendrickson. 
GOPPELT, L. 1976. Theologie des Neuen Testaments. Göttingen: Vandenhoeck \& Ruprecht.

GREEN, J.B. 1997. The Gospel of Luke. Grand Rapids: Eerdmans.

HAMEL, D. 2006. This man welcomes sinners and eats with them: an examination of Jesus' table praxis. http://markmoore.org.classes/jesusseminar/hamelmeals.pdf Date of access: 15 Sept. 2009.

HOEK, J. 2008. Geroepen in een nieuwe eeuw: geheim en missie van de gemeente. Zoetermeer: Boekencentrum.

KAISER, W.C. 1978. Toward and Old Testament theology. Grand Rapids: Zondervan.

KLEIN, H. 2006. Das Lukasevangelium. Göttingen: Vandenhoeck \& Ruprecht. (Kritisch-exegetischer Kommentar über das Neue Testament.)

KRUGER, P. \& HOFMEYR, J.W. 2009. 'n Era van verandering vir die NG Kerk en Suid-Afrika sedert 1990. Deel 1. Nederduitse Gereformeerde teologiese tydskrif, 50(1 \& 2):135-147.

KRÜGER, P.P. 2009. Die geslag wat nie daar sal wees nie. Die Kerkblad, p. 69. Feb.

KÜNG, H. 1976. The church. New York: Image Books.

LATEGAN, L.O.K. 2005. Die plek en roeping van die Nederduits Gereformeerde Kerk in 'n postmoderne wêreld: riglyne vir kerklike hernuwing. Tydskrif vir Christelike wetenskap, no. 3 \& 4:231-245.

MURRAY, S. 2001. Church planting: laying foundations. Scottdale: Herald.

NIELSEN, J.T. 1979. Het evangelie naar Lucas. de prediking van het Nieuwe Testament. Vol. 1: De prediking van het Nieuwe Testament. Nijkerk: Callenbach.

OLIVIER, I.J. \& VAN DEVENTER, H.J.M. 2004. Kerklike bediening aan die postmoderne stadsmens. In die Skriflig, 38(1):1-28.

REINHARTZ, A. 1999. Reflections on table fellowship and community identity. (In Brenner, A. \& Van Henten, J.W., eds. Food and drink in the biblical worlds. Atlanta: Society of Biblical Literature. p. 227-233.) (Semeia 86.)

SAHU, S. 2008. Life in the kingdom: meal as symbol of Jesus' mission. http://www.publications.villanova.edu/concept/2008/pdfs $\% 2008 /$ sahu $\% 200$ n-line\%20pdf.pdf Date of access: 15 Sept. 2009.

SANDERS, E.P. 1985. Jesus and Judaism. London: SCM.

SMIT, G. 2008. Ekklesiologiese merkers vir missionêre gemeentebediening in 'n postmoderne wêreld. Nederduitse Gereformeerde teologiese tydskrif, 49(1 \& 2):106-117.

STEYN, G.J. 2005. Die NG Kerk se identiteitskrisis. Deel 1: Aanloop, terreine van beïnvloeding en reaksies. Nederduitse Gereformeerde teologiese tydskrif, 46(3 \& 4):550-559.

THERON, P.M. \& LOTTER, G.A. 2008. "Do not be yoked together with unbelievers": challenges for Christians and the church amidst unbelievers in a postmodern context. Nederduitse Gereformeerde teologiese tydskrif, 49(3 \& 4):300-316.

TOMSON, P.J. 1999. Jewish food laws in early Christian community discourse. (In Brenner, A. \& Van Henten, J.W., eds. Food and drink in the biblical worlds. Atlanta: Society of Biblical Literature. p. 193-211.) (Semeia 86.)

TOMSON, P.J. 2001. "If this be from heaven ...": Jesus and New Testament authors in their relation to Judaism. Sheffield: Sheffield Academic Press.

VAN BRUGGEN, J. 1993. Lucas: het evangelie als voorgeschiedenis. Kampen: Kok. (Commentaar op het Nieuwe Testament, Serie 3.) 
VAN BRUGGEN, J. 1996. Het evangelie van Gods zoon: persoon en leer van Jezus volgens die vier evangeliën. Kampen: Kok.

VAN GENDEREN, J. \& VELEMA, W.H. 1992. Beknopte gereformeerde dogmatiek. Kampen: Kok.

VORSTER, N. 2004. Op soek na 'n weg uit fundamentalisme, rasionalisme en relatiwisme. In die Skriflig, 38(4):593-621.

WADELL, P.J. 2007. Toward a welcoming congregation. http://www.baylor. edu/-content/services/document.php/53384.pdf Date of access: 15 Sept. 2009.

WRIGHT, N.T. 1992. The New Testament and the people of God. London: SPCK.

\section{Kernbegrippe:}

heiligheid

inkarnasie

missionêre ekklesiologie

sosiale marginalisering

tafelgemeenskap

tollenaars en sondaars

\section{Key concepts:}

holiness

incarnation

missional ecclesiology

social marginalisation

table fellowship

tax collectors and sinners 